\title{
Deconstructing an Ediacaran frond: three-dimensional preservation of Arborea from Ediacara, South Australia
}

\author{
Marc Laflamme, ${ }^{1}$ James G. Gehling, ${ }^{2}$ and Mary L. Droser ${ }^{3}$ \\ ${ }^{1}$ Department of Chemical and Physical Sciences, 3359 Mississauga Road, Mississauga, Ontario L5L 1C6, Canada 〈marc.laflamme@utoronto.ca〉 \\ ${ }^{2}$ South Australian Museum, North Terrace, Adelaide, South Australia 5000, Australia 〈gehling.jim@ saugov.sa.gov.au〉 \\ ${ }^{3}$ Department of Earth Sciences, University of California, Riverside, California 92521, USA 〈mary.droser@ucr.edu〉
}

\begin{abstract}
Exquisitely preserved three-dimensional examples of the classic Ediacaran (late Neoproterozoic; 570-541 Ma) frond Charniodiscus arboreus Jenkins and Gehling, 1978 (herein referred to as Arborea arborea Glaessner in Glaessner and Daily, 1959) are reported from the Ediacara Member, Rawnsley Quartzite of South Australia, and allow for a detailed reinterpretation of its functional morphology and taxonomy. New specimens cast in three dimensions within sandy event beds showcase detailed branching morphology that highlights possible internal features that are strikingly different from rangeomorph and erniettomorph fronds. Combined with dozens of well-preserved two-dimensional impressions from the Flinders Ranges of South Australia, morphological variations within the traditional Arborea morphotype are interpreted as representing various stages of external molding. In rare cases, taphomorphs (morphological variants attributable to preservation) represent composite molding of internal features consisting of structural supports or anchoring sites for branching structures. Each primary branch consists of a central primary branching stalk from which emerge several oval secondary branches, which likely correspond to similar structures found in rare two-dimensional specimens. Considering this new evidence, previous synonymies within the Arboreomorpha are no longer justified, and we suggest that the taxonomy of the group be revised.
\end{abstract}

\section{Introduction}

The Ediacara biota represents an assemblage of large, soft-bodied, and structurally complex organisms of uncertain affinities (Laflamme et al., 2013; Droser and Gehling, 2015). Earliest attempts to classify these organisms, on the basis of morphological comparisons with modern taxa, resulted in their interpretation as primitive examples of crown-group animals (see Glaessner, 1979); however, recent studies instead suggest that the Ediacara biota consists of a number of distinct groups rather than a single clade, thus shifting the debate to discussions of stem animals and crown animals and clades outside of Metazoa (Xiao and Laflamme, 2009; Erwin et al., 2011; Laflamme et al., 2013; Dececchi et al., 2017; although see Budd and Jensen, 2015). Their disappearance prior to the diversification of complex metazoans has been proposed to represent the first biologically driven mass extinction event (Darroch et al., 2015, 2016; Schiffbauer et al., 2016). The term 'Ediacara biota' is herein applied to the cast and mold impressions of soft-bodied organisms of uncertain affinity from the Ediacaran Period (MacGabhann, 2014).

Erwin et al. (2011) proposed a new classification for Ediacaran macrofossils, which utilizes features such as branching or segment architecture, body symmetry, associated trace fossils, and growth parameters, to erect distinct higher-level groupings based on shared (presumed derived) morphological, behavioral, and ontogenetic characters, while eliminating traditional groupings based on implied ecological similarities (see discussions in Laflamme and Narbonne, 2008a, b). This classification restricts direct comparisons with modern taxa unless synapomorphies are shared. One such proposed clade, the Arboreomorpha, consists of fronds with typically bifoliate (possibly multifoliate) petaloids with parallel primary branches that are attached to a sheet and end at an outer rim (Erwin et al., 2011; Laflamme et al., 2013; Dececchi et al., 2017). The Arboreomorpha are distinct from Rangeomorpha in lacking a self-repeating and modular branching pattern (Laflamme and Narbonne, 2008a, b; Erwin et al., 2011; Brasier et al., 2012); instead, the secondary branches are globular and typically lack further subdivisions. A similar classification scheme proposed the "Frondomorpha" for Charniodiscus (in addition to other fronds and an assortment of likely holdfasts), defined as Ediacaran fossils "composed of three distinct parts: a large, relatively flattened foliate section, a central stem, and a holdfast or rooting anchor" (Grazhdankin, 2014, p. 271-272). However, this definition would include Rangeomorpha such as Charnia, Beothukis, and Culmofrons and Erniettomorpha such as Swartpuntia (Dececchi et al., 2017); instead, it is most likely that the frond morphology is a shared morphological adaptation to elevating a feeding structure into the water column (Laflamme and Narbonne, 2008a).

The Arboreomorpha are known from the Avalon and White Sea assemblages (Waggoner, 2003; Boag et al., 2016), with specimens described from Newfoundland (Canada), Charnwood Forest (England), White Sea (Russia), Ukraine, Siberia, Wernecke and Mackenzie Mountains (northwestern 
Canada), the Yangtze Gorges area of South China, and the Ediacara Member of the Flinders Ranges of South Australia. All known Arboreomorpha are benthic epifaunal fronds that effectively partitioned the water column on a macroscopic level, resulting in complex tiered Ediacaran ecosystems (Clapham and Narbonne, 2002; Ghisalberti et al., 2014).

The limited taphonomic windows offered by most Ediacaran localities preserve impressions of two-dimensional casts and molds in medium to coarse sandstones (Narbonne, 2005; Kenchington and Wilby, 2014), limiting morphological information to external structures. Taphonomic studies distinguishing between genuine structures and morphological "mistakes" resulting from bending, folding, or overlapping relationships have been essential in forwarding taxonomic and phylogenetic research (Laflamme et al., 2007; Liu et al., 2011; Brasier et al., 2013; Matthews et al., 2017). Rare glimpses into three-dimensional morphology are offered by exceptional sites in Namibia (Vickers-Rich et al., 2013; Ivantsov et al., 2016), Newfoundland (Narbonne, 2004; Narbonne et al., 2009), and the White Sea (Grazhdankin, 2014; Ivantsov, 2016).

The discovery of several exquisitely preserved, threedimensional examples of the classic Ediacaran frond Arborea (previously Charniodiscus, see systematic taxonomy) from the Ediacara Member, Rawnsley Quartzite of South Australia, allows for the reevaluation of this genus and adds insight into the internal construction and likely external morphology of this frond. Preservation of inferred internal anatomy, combined with detailed preservation of the branching architecture, also helps refine the classification of Arboreomorpha.

\section{Geological setting and stratigraphy}

The Ediacaran assemblages found within the Flinders Ranges of South Australia contain some of the highest diversity of Ediacara biota (Droser et al., 2006; Droser and Gehling, 2015), the broadest range of occupied ecological niches (Bambach et al., 2007; Bush et al., 2011; Laflamme et al., 2013), and the first probable examples of stem-group Bilateria anywhere in the world (Fedonkin and Waggoner, 1997). Ediacaran fossils in South Australia are typically restricted to the Ediacara Member of the Rawnsley Quartzite (Gehling, 2000; Gehling and Droser, 2013) in the upper portion of the Pound Subgroup, Wilpena Group, which overlies the global Marinoan glacial tillite that marks the base of the Ediacaran Period (Knoll et al., 2006). Volcanic ash layers are unknown from the Flinders Ranges; however, paleobiological studies have linked the Flinders Ranges with the White Sea assemblage of Russia (Waggoner, 2003; Boag et al., 2016), which has been radiometrically dated at $555 \mathrm{Ma}$ (Martin et al., 2000).

For over a decade, diligent excavations of complete Ediacaran surfaces from the National Heritage Listed Ediacara Fossil Site at Nilpena (herein referred to as Nilpena) in the Flinders Ranges of South Australia (see reviews in Droser et al., 2006; Gehling and Droser, 2013; Droser and Gehling, 2015) have uncovered a diverse assemblage of Ediacara biota occupying specific ecological niches and representative sedimentary facies including shoreface sands, wave-base sands, delta-front sands, sheet-flow sands, and mass-flow sands. Although Arborea is known from all these facies, wave-base and sheet-flow sands offer the greatest abundance of specimens (Gehling and Droser, 2013); however, the mass-flow sands facies has been responsible for exquisite, three-dimensional preservation of large Arborea fronds allowing for unprecedented levels of morphological detail. For our purposes, 3D preservation is distinguished from typical Ediacaran two-dimensional preservation as representing moldic sand infills that can be isolated and removed from external molds in the surrounding matrix.

\section{Taphonomy}

The influence of taphonomy on Ediacaran taxonomy is profound. Although emerging taphonomic studies demonstrate a common reliance on clays and bacterially mediated precipitation of iron sulfides associated with Ediacaran preservation (Gehling, 1999; Laflamme et al., 2011, Darroch et al., 2012; Schiffbauer et al., 2014; Liu, 2016), Ediacaran-type preservation spans a remarkably large lithological spectrum, resulting in an equally expansive range of taphomorphs (Grazhdankin et al., 2008; Xiao et al., 2013; Kenchington and Wilby, 2014). Distinct preservational styles (of Narbonne, 2005) are typically limited to single localities, representing an intimate association between sedimentary facies, depositional context, and ambient water energy irrespective of the qualities of biological tissue constructing these organisms.

Preservation of the soft-bodied Ediacara biota from South Australia results from the intimate relationship between the organisms and expanses of seafloor microbial mats (Gehling, 1999; Gehling et al., 2005; Gehling and Droser, 2009; Darroch et al., 2012). The 'death mask' model (Gehling, 1999) predicts that after burial by storm deposits, new colonies of microbial mats restricted the transport of oxygenated pore waters into the underlying sands. In the presence of decaying organic material (i.e., buried microbial mats and Ediacara biota), sulfate trapped in the pore waters was reduced through the metabolic activities of sulfur-reducing bacteria, resulting in pyritic coatings that form the basis of Flinders-type preservation (Narbonne, 2005). Evidence such as pyritized bacterial mats (Gehling et al., 2005), 'old elephant skin' (Gehling, 1999), preserved microbial filaments (Gehling et al., 2005; Callow and Brasier, 2009), and microbially induced sedimentary structures (Gehling and Droser, 2009) on the beds containing fossils all suggest a direct link between bacterial mats and Ediacaran preservation. Recently, it has been suggested that the relatively higher silica saturation state of Neoproterozoic oceans prior to the advent of abundant silica biomineralizers aided in rapid sediment lithification via early-stage precipitation of silica cements (Tarhan et al., 2016).

New discoveries of exquisitely preserved Ediacaran fronds from Nilpena Farm in South Australia exhibit three-dimensional casting of soft-bodied Ediacaran organisms within fine-grained event beds resulting from storm or mass-flow events. The three-dimensional casting has been essential in differentiating multiple petaloids in multifoliate fronds such as Rangea and Swartpuntia (Narbonne et al., 1997; Vickers-Rich et al., 2013) and typically results in finer-detailed preservation (Narbonne, 2004; Narbonne et al., 2009). It was proposed by Dzik (1999) and Narbonne (2005) that Nama-style preservation may allow for the casting of internal rather than external features, therefore 
revealing hypothesized internal, soft-bodied organic skeletons serving as primary structural supports for epifaunal fronds.

The combination of a variety of preservational types of the same taxon within a single, temporally restrictive locality provides a unique opportunity to dissect the internal and external morphology of an Ediacaran organism and refines the interpretation of characters preserved in two-dimensional casts.

\section{Frond morphology and the history of Charniodiscus and Arborea}

Ediacaran fronds (Fig. 1) represent a convergent evolution toward a shape that elevates a foliate feeding structure higher into the water column (Laflamme and Narbonne, 2008a, b) to effectively reduce competition with crowded lower tiers (Clapham and Narbonne, 2002; Ghisalberti et al., 2014). Arboreomorpha frond morphology consists of a basal anchoring structure typically circular to bulbous in shape, which was either buried beneath/within (Tarhan et al., 2010; Laflamme et al., 2011; Burzynski and Narbonne, 2015) or stuck to the upper surface (Seilacher, 1992) of benthic microbial mats. The anchoring disc was attached to a cylindrical stem from which emerged a bifoliate petalodium (possibly multifoliate; Brasier and Antcliffe, 2009). Petaloids are composed of several primary branches that branch off directly from the central stalk.

The poor preservation of the holotype of Charniodiscus concentricus Ford, 1958 makes it difficult to evaluate the nature of the petalodium. Brasier and Antcliffe (2009, fig. 12) suggested that $C$. concentricus could represent a multifoliate frond, consisting of several independent petaloids all circling a central stalk ("Laser scanning also suggests that Charniodiscus concentricus had three or more rows of segments [Dzik 2002], much like Rangea [Gurich 1929, 1930; Germs 1973; Jenkins 1985] and Swartpuntia [Narbonne et al. 1997], rather than the two rows..."; Brasier and Antcliffe, 2009, p. 372), and that much of the disorganization of the petaloidium could be explained by overfolded petaloids ("Interpretative drawing showing inferred presence of three or more rows of $1^{\circ}$ branches" [note ' $1{ }^{\circ}$ branches' $=$ primary branches, and 'rows' $=$ petaloids]; Brasier and Antcliffe, 2009, p. 375). The multifoliate nature of the holotype was also proposed by Dzik (2002), who suggested that the poor preservation may have resulted from the presence of "more than two vanes" (vanes=petaloids; Dzik, 2002, p. 322) and that "available evidence from Charniodiscus is compatible with the four-vane model of Rangea anatomy" (Dzik, 2002, p. 322). If true, the multifoliate petalodium in C. concentricus is strikingly different from Australian specimens presently referred to as $C$. arborea and C. oppositus Jenkins and Gehling, 1978, which display clear bifoliate symmetry with only two petaloids. We propose that this represents a fundamental difference in construction, and as a result we follow the recommendations of Brasier and Antcliffe (2009) and Dzik (2002) in referring to C. arborea and C. oppositus as Arborea Glaessner and Daily, 1959.

Another contentious aspect concerns the architecture of the primary branches in Charniodiscus and Arborea. Brasier and Antcliffe (2009) interpreted the primary branches in the holotype of $C$. concentricus as repeatedly branched elements that resemble the fractal branching of rangeomorphs such as Charnia and Rangea (Narbonne, 2004; Dececchi et al., 2017), albeit not as well preserved. When investigating the secondary branching in the holotype, Brasier and Antcliffe (2009) concluded that "Laser profiles confirm that these arcuate $1^{\circ}$ branches are further subdivided into numerous $2^{\circ}$ branches. Their rangeomorph structure is not displayed. No examples of $3^{\circ}$ or $4^{\circ}$ branches have yet been seen in the holotype" (Brasier and Antcliffe, 2009, p. 372). This condition was further explored by Brasier et al. (2012), who applied the term 'furling' to account for the difference in structure between typical rangeomorphs and Charniodiscus: "rangeomorph units furled but undivided at first-order level, so that second-order subdivisions cannot be seen (cf. some examples of Charniodiscus)" (Brasier et al., 2012, p. 1111). By contrast, Laflamme et al. (2004) and Laflamme and Narbonne (2008a) argued that Arborea from Australia were composed of a series of parallel, peapod-like primary branches that housed several oval secondary branches that lacked modular subdivisions; this branching was termed Arborea-type branching (Laflamme and Narbonne, 2008a). The crux of this distinction in branching, either a furled rangeomorph branch (Brasier et al., 2012) or a morphologically (and evolutionarily) distinct arboreomorph branch (Laflamme and Narbonne, 2008a), will play heavily in our continued attempts to decipher the natural history of these Ediacaran clades. The debate can be summarized as the explanation of the simplified branching morphology seen in Charniodiscus (holotype) and Arborea - does it represent a modified (or poorly preserved) rangeomorph branch, thus allying them with Rangea and Charnia, or does it represent an independent ancestry, thus justifying Arboreomorpha as a clade (Dececchi et al., 2017)?

In summary, assuming that: (1) the petaloid arrangement in Arborea from Australia is distinct from the structure in Charniodiscus from England (multifoliate), and (2) the primary branching architecture (rangeomorph vs. arboreomorph) may also be distinct, we recommend the use of the traditional Australian designation of Arborea to represent bifoliate fronds with Arborea-type primary branching from Australia, while Charniodiscus is kept for multifoliate frondose forms from Charnwood Forest England. Considering these new diagnostic structures, a revision of Newfoundland Charniodiscus material is warranted but beyond the scope of this study. Ultimately, the present study of exceptionally preserved Arborea allows for a refined description of Arboreomorpha primary branches (Dececchi et al., 2017) as presented in the Systematic Paleontology.

\section{Materials and methods}

With the discovery of multiple, three-dimensionally preserved Arborea fronds from Nilpena in the Flinders Ranges of South Australia, the architecture of the primary branches can be thoroughly evaluated. Furthermore, by comparing various taphomorphs of Arborea from South Australia, it is possible to differentiate between dorsal and ventral sides of the petalodium and isolate internal structures that are preserved as composite molding.

Repository and institutional abbreviation.-In the following section, a new description of Arborea is based on 84 specimens from the South Australian Museum (SAM). 


\section{Systematic paleontology}

Clade Arboreomorpha Erwin et al., 2011

Remarks.-Currently there is no agreed-upon taxonomic hierarchy for Ediacara biota above the rank of genus. For this reason, the term "Clade" is applied to indicate a group of closely related Ediacara biota. See Erwin et al. (2011) and Laflamme et al. (2013) for discussion and rationale.

Phylum, Class, Order, and Family indeterminate

Genus Arborea Glaessner and Wade, 1966

Figures 1-8

1959 Rangea arborea Glaessner in Glaessner and Daily, pls. 43.1-3, 44.1-3, 45.1, 2.

1966 Arborea arborea Glaessner and Wade, p. 623, pl. 102, figs. $1,2$.

1978 Charniodiscus arboreus; Jenkins and Gehling, p. 350, fig. 3.

1978 Charniodiscus oppositus; Jenkins and Gehling, p. 204, pl.3, fig. 4.

2013 Charniodiscus sp.; Gehling and Droser, p. 449, fig. 2c.

Type species.—Rangea arborea Glaessner in Glaessner and Daily, 1959.

Diagnosis.-New. Frond with ovate bifoliate petalodium composed of prominent stalk and multiple parallel primary branches stemming between $45^{\circ}$ and $90^{\circ}$ from stalk. Petalodium tapers distally. Primary branches sinusoidal to rectangular. Primary branching stalk runs the entire length of the branch. Secondary branches oval, broaden distally and taper proximally, where they are anchored to the primary branching stalk. Secondary branches lack branching subdivisions.

Occurrence.-Ediacaran of Russia, Ukraine, Australia, England, China, and Canada.

Arborea arborea Glaessner in Glaessner and Daily, 1959

1959 Rangea arborea Glaessner in Glaessner and Daily, pls. $43.1-3,44.1-3,45.1,2$.

1966 Arborea arborea Glaessner and Wade, p. 623, pl. 102, figs. 1, 2.

1978 Charniodiscus arboreus; Jenkins and Gehling, p. 350, fig. 3.

1979 Charniodiscus arboreus; Glaessner, p. 100, fig. 12.2c.

1996 Charniodiscus arboreus; Jenkins, p. 36, fig. 4.2a, b, 4.3.

2001 Charniodiscus arboreus; Narbonne, Dalrymple, and Gehling, p. 26, pl. 1d.

2004 Charniodiscus arboreus; Laflamme, Narbonne, and Anderson, p. 832, fig. 4.5.

2013 Charniodiscus sp.; Gehling and Droser, p. 449, fig. 2c.

Holotype.- P12891, South Australian Museum.

Description.-Holotype (P12891) incomplete. Petalodium incomplete, $15 \mathrm{~cm}$ long by $5.5 \mathrm{~cm}$ wide, with at least 20 primary
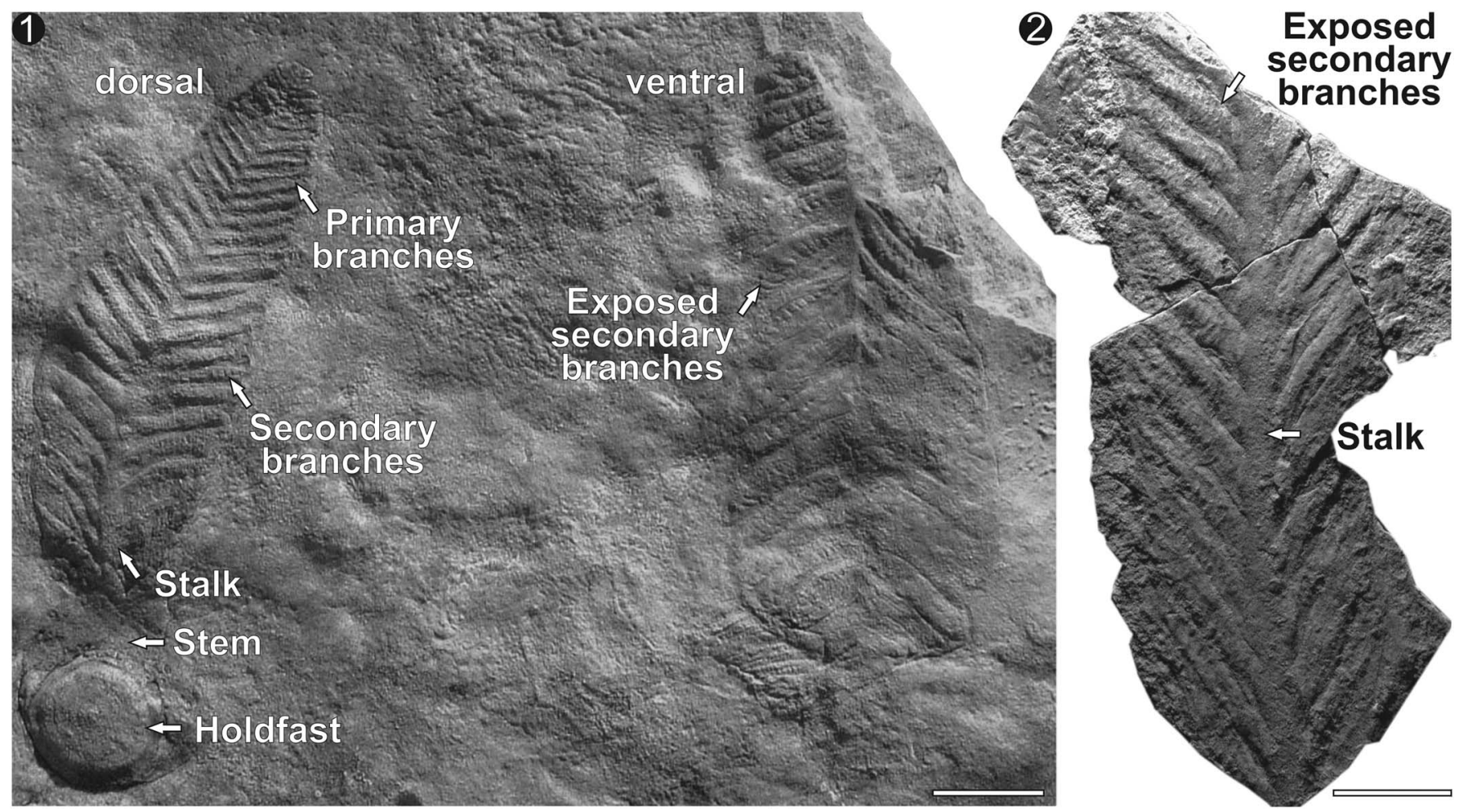

Figure 1. Frond morphology: (1) SAM P19690a, b representing dorsal and ventral sides, respectively, on the sole of a $30 \mathrm{~cm}$ thick sandstone bed from Bunyeroo Gorge. (2) SAM P49416. Each petaloid consists of numerous primary branches attached to a central stalk and composed of several secondary branches. Petalodium attached to a stem and anchored by a circular holdfast disc. Scale bar $=5 \mathrm{~cm}$. 

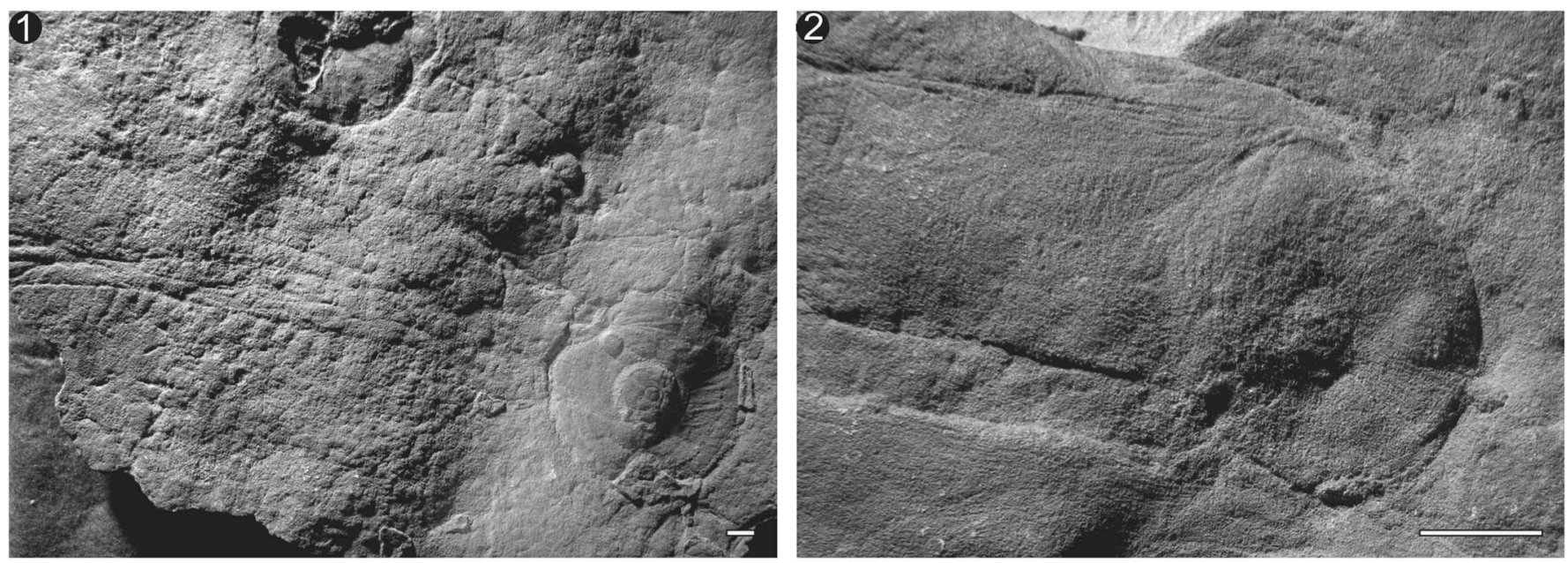

Figure 2. Circular Arborea holdfasts attached to cylindrical stem. (1) Specimen P14186 with large central boss and several radial striations most likely representing soft-tissue folding during compression. (2) Specimen P40332 with deflated disc similar in size to the stem. Scale bars $=1 \mathrm{~cm}$.

branches. Probable secondary branches preserved on isolated branches. Stem and holdfast not preserved.

Remarks.-Circular discs closely associated with stems and fronds (Fig. 2) are interpreted as rooting holdfasts. In relatively low-energy settings, frond specimens are typically attached to an anchoring disc (Laflamme et al., 2004). However, the higherenergy setting of Ediacara, South Australia, results in the overwhelming majority of circular holdfasts being disassociated from their respective fronds, having been presumably plucked away from the sediment, leaving distinct sedimentary structures in their place (Tarhan et al., 2010). Furthermore, several instances of surface expressions of collapsed craters with stalks likely represent deflated or collapsed holdfasts (Tarhan et al., 2010). Holdfasts were bulbous in shape, resulting in a prominent surface expression in addition to a significant portion of the holdfast that lay beneath (or within) the microbial mat, preferentially biasing its preservation over the complete frond (Laflamme et al., 2011). To date, no known trace fossils have been found directly associated with the discs (although see Liu et al., 2010; Menon et al., 2013), so whether the frond was capable of burrowing with its rooting holdfast is difficult to speculate.

The stem in Arborea (Figs. 1,2.2) is typically flattened and rectangular in most specimens, although it is interpreted as being originally cylindrical in shape. The stem was most likely composed of a structurally rigid material that restricted compaction during fossilization (Laflamme et al., 2004). In South Australia, frond stems are uncommon but represent the basal extension of the stalk (Fig. 2.1).

The stem continues into the petalodium to form the stalk (Fig. 1). The stalk varies in shape, from strongly parallel-sided (Fig. 3.1) to an alternating, sinuous (zigzagging) central axis (Fig. 3.2-3.4). The stalk is typically preserved in positive relief, suggesting it may be constructed of similar material as the stem. The variation in stalk morphology has been suggested as a means of taxonomically differentiating Arborea species (Jenkins and Gehling, 1978), although reevaluation of specimens from South Australia reveals a seamless transition between specimens representing a parallel-sided cylindrical stalk and those with a sinuous, alternating stalk (Fig. 3.5). In specimens with a parallel-sided stalk (Fig. 3.1), the primary branches appear to terminate at the stalk boundary, whereas in specimens with a sinuous stalk, the primary branches go beyond the boundary of the central stalk and meet at the central axis (Fig. 3.2). In these cases, the outer margin of the central stalk appears sinuous in shape due to the alternating branching pattern along the central axis. It is possible that the cylindrical and sinuous stalks represent the dorsal and ventral aspects of the fronds, respectively. This hypothesis would imply that the anchoring points of the primary branches, whether they be found on the ventral or dorsal side, are only preserved when the respective side of the frond is preserved. This may be the case in some instances; however, specimen P40444 (Fig. 3.4) showcases an alternative interpretation. This specimen shows a transition between end members: a cylindrical (Fig. 3.4A) to a sinuous (Fig. 3.4C) stem. We propose that the difference in stalk shape could represent a taphonomic artefact resulting from compression of the cylindrical stem and the composite molding of the alternating primary branching stalks.

The primary branches are attached to the central stalk, while the smaller secondary branches stem perpendicularly from the primary branch stalk (Figs. 1, 4). Reported tertiary branches are typically poorly preserved and likely represent a taphonomic artefact resulting from wrinkling or folding of soft tissue. Presumed well-preserved examples of secondary branching lack any evidence of tertiary branching, and instead suggest a smooth, teardrop shape for the secondary branches (Figs. 5-7). Primary branches in Arborea are strongly parallel along their entire length, suggesting that they are attached to each other or to a dorsal sheet (Fig. 4.6) or strongly anchored to the stalk proximally, and distally connected to an outer rim (Fig. 1.1; although see Fig. 8 and discussion in the following). The primary branches vary in shape, from cylindrical (Fig. 4.1) to sinuous with strongly tapering proximal and distal terminations (Fig 4.6).

Secondary branches vary in shape, from straight to slightly curved structures emanating upward (rarely downward) from the primary branches (Figs. 5-7). In rare instances, the secondary branches are preserved as teardrops with the tapering 

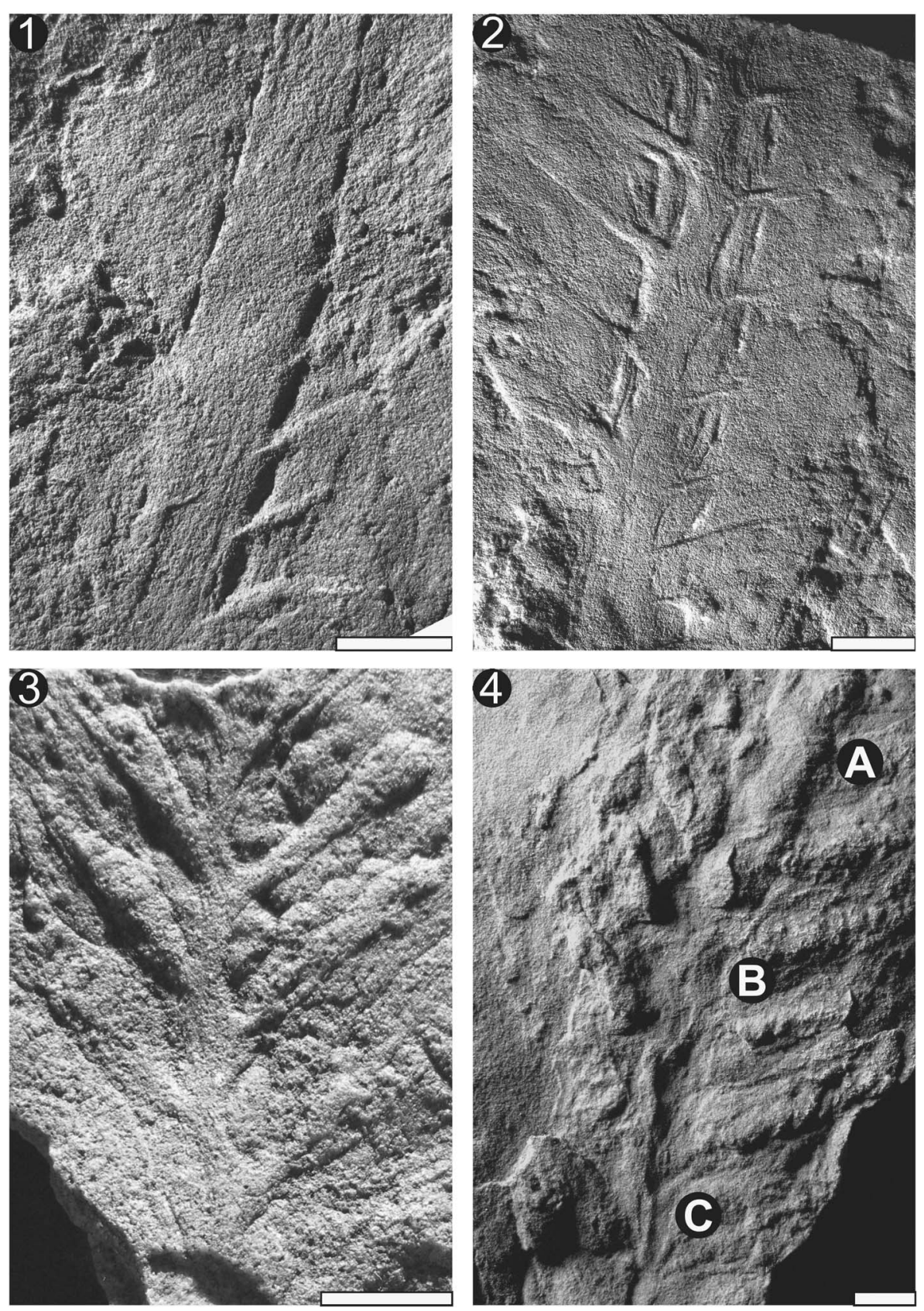
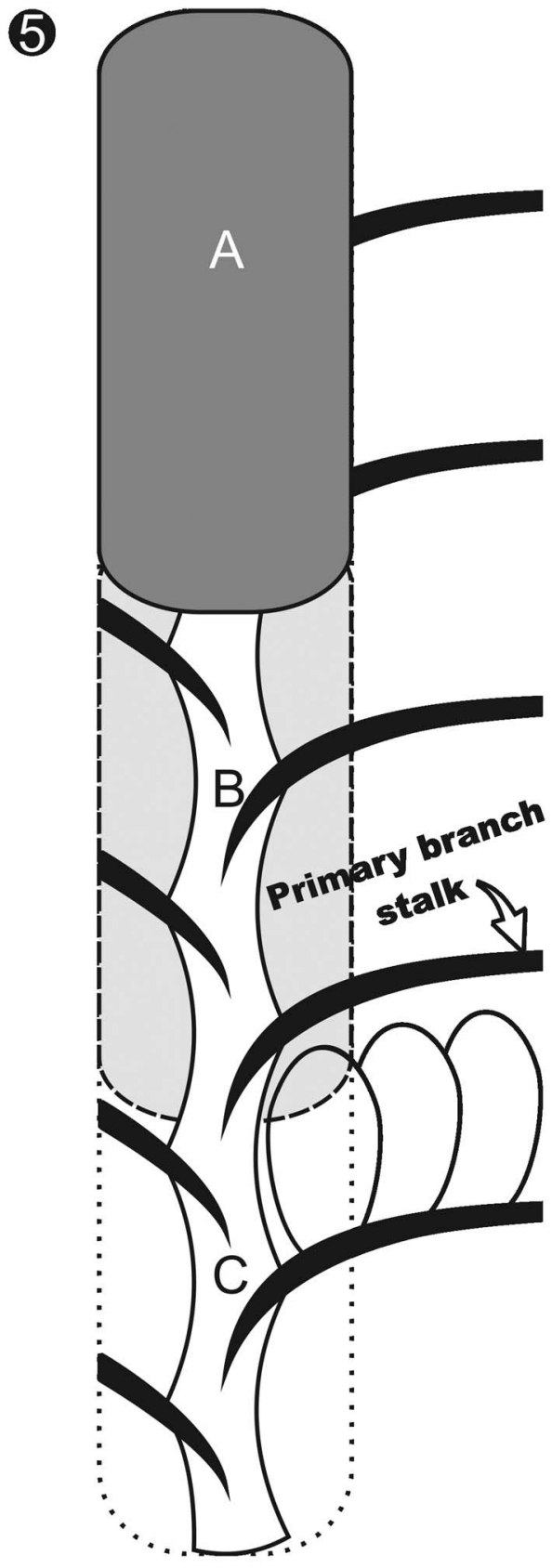

Figure 3. Stalk: taphonomic variations in stalk morphology. (1) Specimen P13800 with cylindrical stalk and peg-like primary branches originating from within the boundaries of the stalk. (2) Specimen P12895 with parallel-sided stalk and zigzagging central axis resulting from alternating primary branching architecture. (3) Specimen P40952 with alternate branching to form a zigzagging central axis but lacking the outline of the cylindrical stalk seen in (2). (4) Specimen P40444 displaying all three $(\mathrm{A}-\mathrm{C})$ stalk morphologies. Letters along stalk refer to taphomorphs highlighted in $(\mathbf{1 - 3})(\mathrm{A}=1, \mathrm{~B}=2, \mathrm{C}=3)$. (5) Interpretive diagram of the three stalk taphomorphs with letters for reference. Compaction results in flattening of the stalk and composite molding of the primary branches. (1-4) Scale bars $=1 \mathrm{~cm}$.

end serving as the attachment structure to the primary branch stalk (Figs. 5.5, 6.2-6.4). Attachment of the secondary branches is limited to their proximal region only, allowing for the distal portions of the branches to be displaced and overlap with adjacent branches (black arrow in Fig. 6.3). In some instances, the distal portions of the secondary branches continue far beyond the boundaries of their primary branches and are preserved overlying the proximal portion of the (distally) adjacent primary branch (Figs. 5.2, 7.1-7.3). This implies that secondary branches are not contained within the primary branches like peas in a pod (as suggested by Jenkins, 1996;
Laflamme and Narbonne, 2008a). Finally, secondary branches can pivot upward (most-typical orientation) and downward (less-typical orientation; Fig. 7).

Arborea in South Australia always possesses a bifoliate petaloid. A thick outer rim is typically preserved (Fig. 1.1); however, the rim can be indented and not uniformly preserved along the entirety of the petalodium (Figs. 1.1, 4.6) or even completely lacking. Specimens that preserve the distal termination of the primary branches are rounded (Fig. 8) and seemingly lack an attachment rim. These specimens suggest that the 'rim' most likely represents a preservational artefact resulting from 

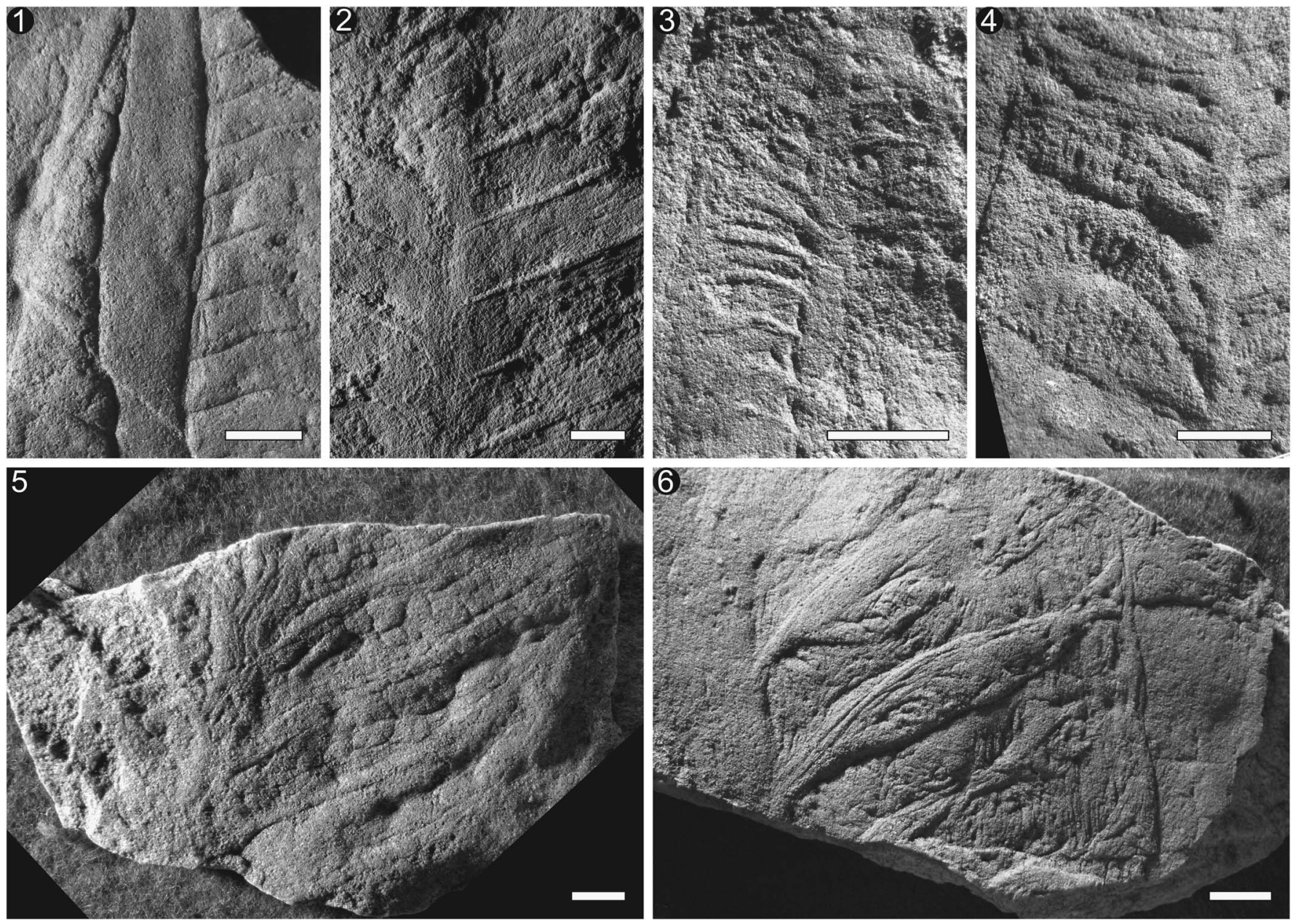

Figure 4. Primary branching morphology in Arborea from the Ediacara Member of the Pound Subgroup. Branches arranged in increasing quality of preservation, from poorest-preserved branches to highest-quality preservation with secondary and possibly tertiary branching exposed. (1) Specimen P34499 displaying parallel rectangular primary branches with possible secondary branching structures perpendicular to the primary branches. (2) Specimen P13801b with peg-like margins to the primary branches that pass beyond the margin of the stalk, suggesting the anchoring site is internal to the stalk and preserved as a composite mold. (3) Specimen P14307 with primary branches composed of peg-like structures. (4) Specimen P40775 displaying an arched primary branch with distinct secondary branching emerging from the base of the branch and overlying the base of the subsequent adjacent branch. (5) Specimen P40776 with welldefined cylindrical primary branch stalks and rounded to globular secondary branching. Secondary branching begins in the middle of the primary branch, attached to the primary branching stalks. (6) Specimen P40786, with higher-relief primary branches and with evidence of an organic sheet behind the branches, attaching them together and preventing significant branch movement. All scale bars $=1 \mathrm{~cm}$.

the folding or rolling-up of the soft-bodied primary branches at their distal tips.

Comparisons.-Arborea is most similar to Charniodiscus in construction, with both genera sharing an ovate petalodium attached to a stem and anchored to the substrate by a circular to bulbous holdfast. Arborea can be distinguished from Charniodiscus concentricus by the bifoliate petalodium and the smaller number of primary branches that are more uniform in size and shape.

\section{Reconstruction of Arborea}

A detailed reconstruction of Arborea is possible by comparing the best-preserved two-dimensional molds of Arborea with the newly discovered three-dimensional specimens. The most important change proposed by the reevaluation of Arborea concerns the morphology of the petalodium. The morphology of the stalk varies from a smooth, featureless rectangle to a zigzagging central axis, with numerous examples forming a transition between end members (Fig. 3). Cylindrical stalks are believed to represent instances in which the stalk was quickly filled with sediment thus resisting compaction or, alternatively, was buried rapidly and therefore did not undergo significant decay prior to burial, which would have compromised the strength of the integument. This morphotype typically lacks the preservation of the anchoring points of the primary branch stalks, presumably due to the difficulty in preserving composite molds when the stalk is sand-filled. The sinuous stalk is believed to represent the compaction of the stalk and the resulting composite molding of the alternating primary branch stalks as they overprint the central stalk (Fig. 3.5).

The primary branches also vary greatly in shape due to different degrees of preservation. For example, the gradation from rectangular primary branches that tend to lack secondary branches (Fig. 4.1) into sigmoidal branches with well-defined secondary branches (Fig. 4.4-4.6) can be explained through taphonomic variation. Cylindrical branches are typically 

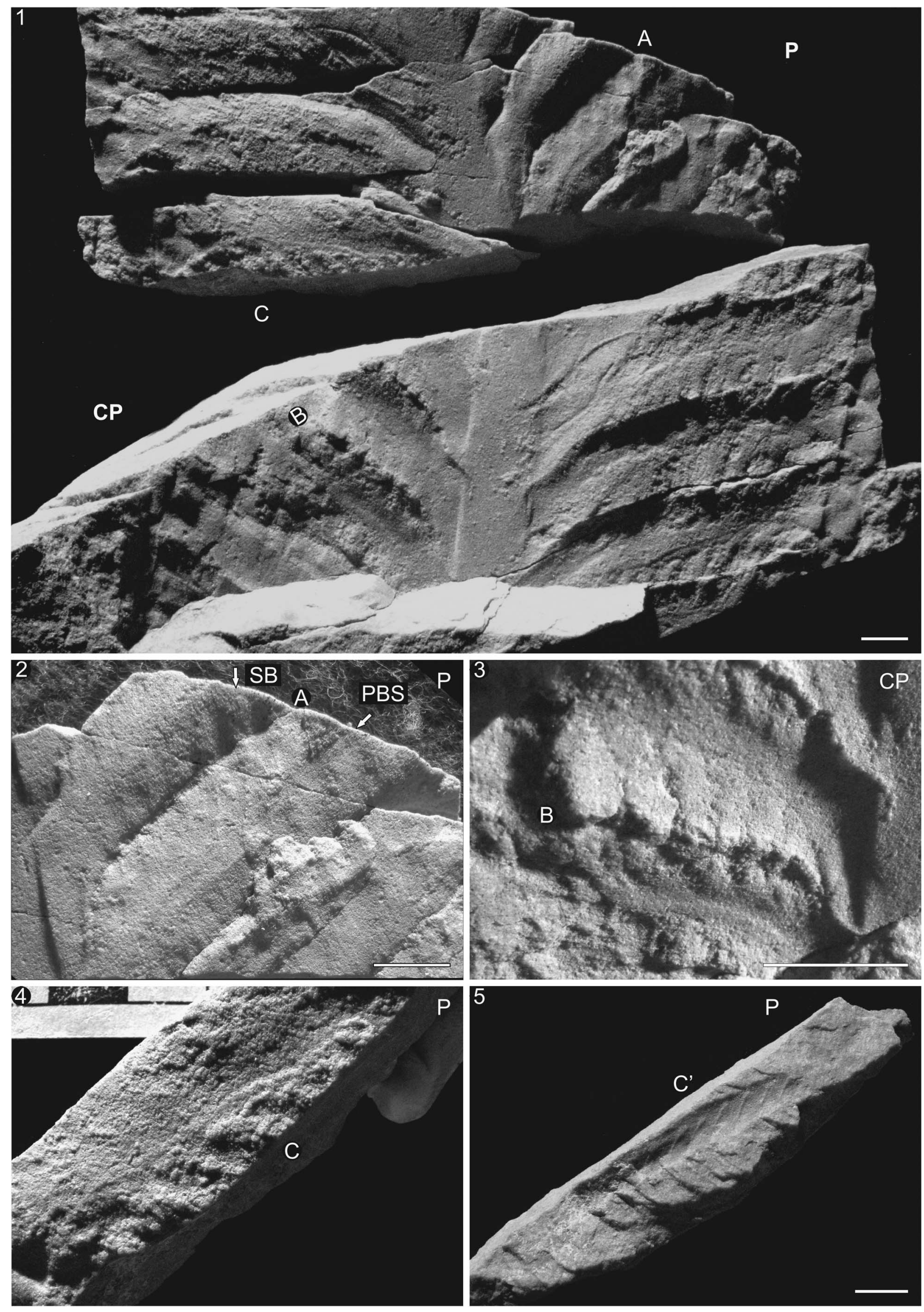

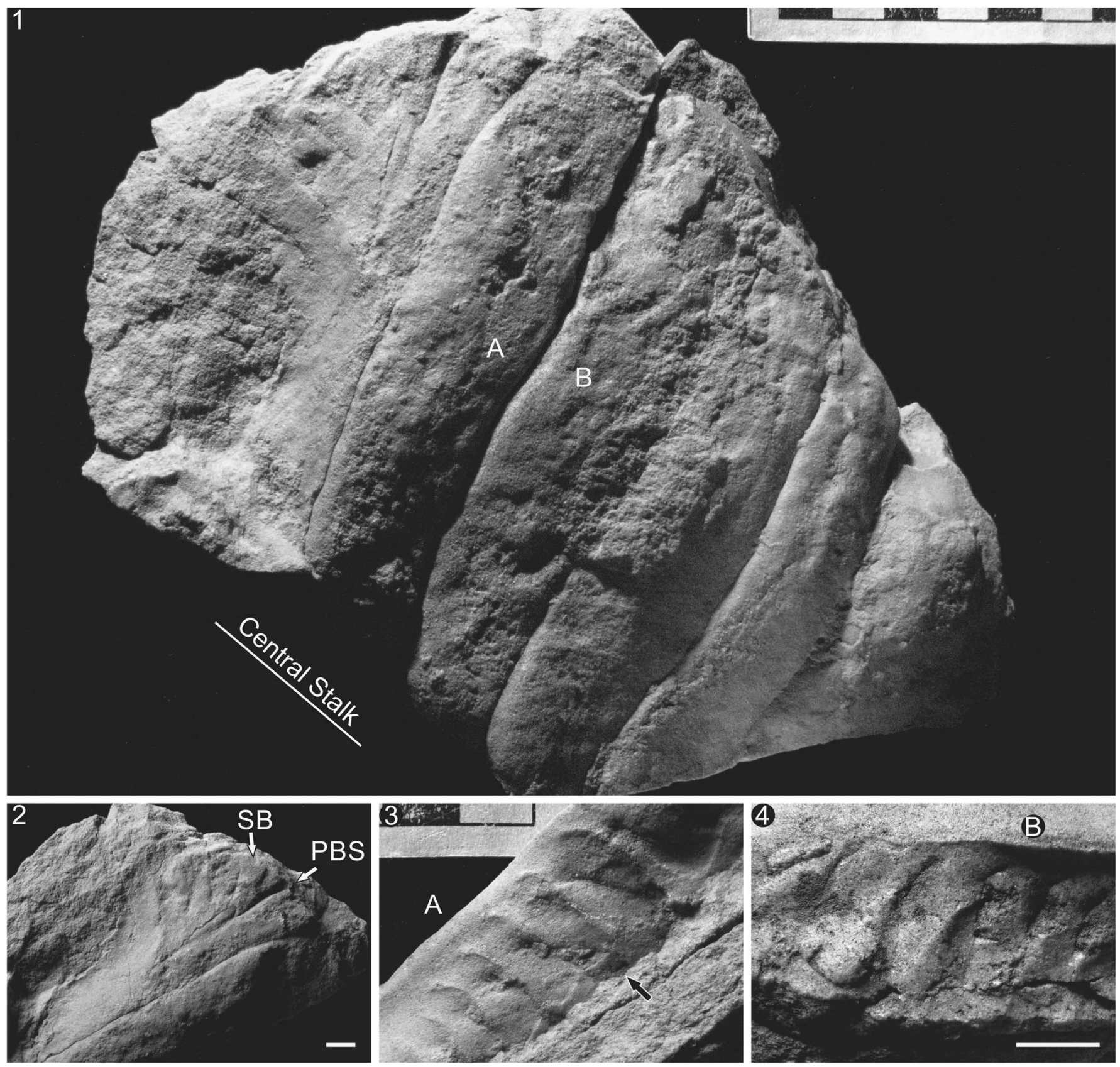

Figure 6. Specimen P49364a, b from Nilpena Farm: (1) Specimen preserved in three dimensions. Presumed location of central stalk according to branching orientation. (2) Primary branch displaying secondary branches (SB) stemming from the primary branching stalk (PBS). (3, 4) Part and counterpart of a (A) cross section through a primary branch broken away from adjacent branches and displaying (B) teardrop secondary branches. Black arrow indicates location of displaced secondary branch. Scale bars $=1 \mathrm{~cm}$ or $1 \mathrm{~cm}$ increments.

associated with specimens in which the central stalk is also cylindrical (rather than sinuous). The strongly positive relief and well-defined boundaries of the stalk cut off the proximal portion of the branches, resulting in a more rectangular primary branch (Figs. 3.1, 4.1). By contrast, sinuous primary branches are typically found associated with zigzagging central stalks
(Figs. 3.2-3.3, 4.5). As such, the sigmoidal shape of the primary branches most likely results from the preservation through composite molding of the alternating proximal attachment to the stalk.

The presence or absence of secondary branches is typically explained as a taphonomic variation, with well-preserved

Figure 5. Secondary branches in SAM P35702 from Nilpena Farm: (1) Part (P) and counterpart (CP) of specimen preserved in three dimensions, displaying prominent central stalk and several primary and secondary branches. (2) Close-up of two primary branches (A) displaying the secondary branches (SB) stemming from the primary branch stalk (PBS) and crossing over the furrow between the primary branches. (3) Same primary branches as (2) but in counterpart specimen (B). (4) Top view of broken piece of primary branch displaying secondary branching (C). (5) Same piece as (4) (C') but rotated on its side to show side profile of peg-like secondary branches. Scale bars $=1 \mathrm{~cm}$ or $1 \mathrm{~cm}$ increments. 

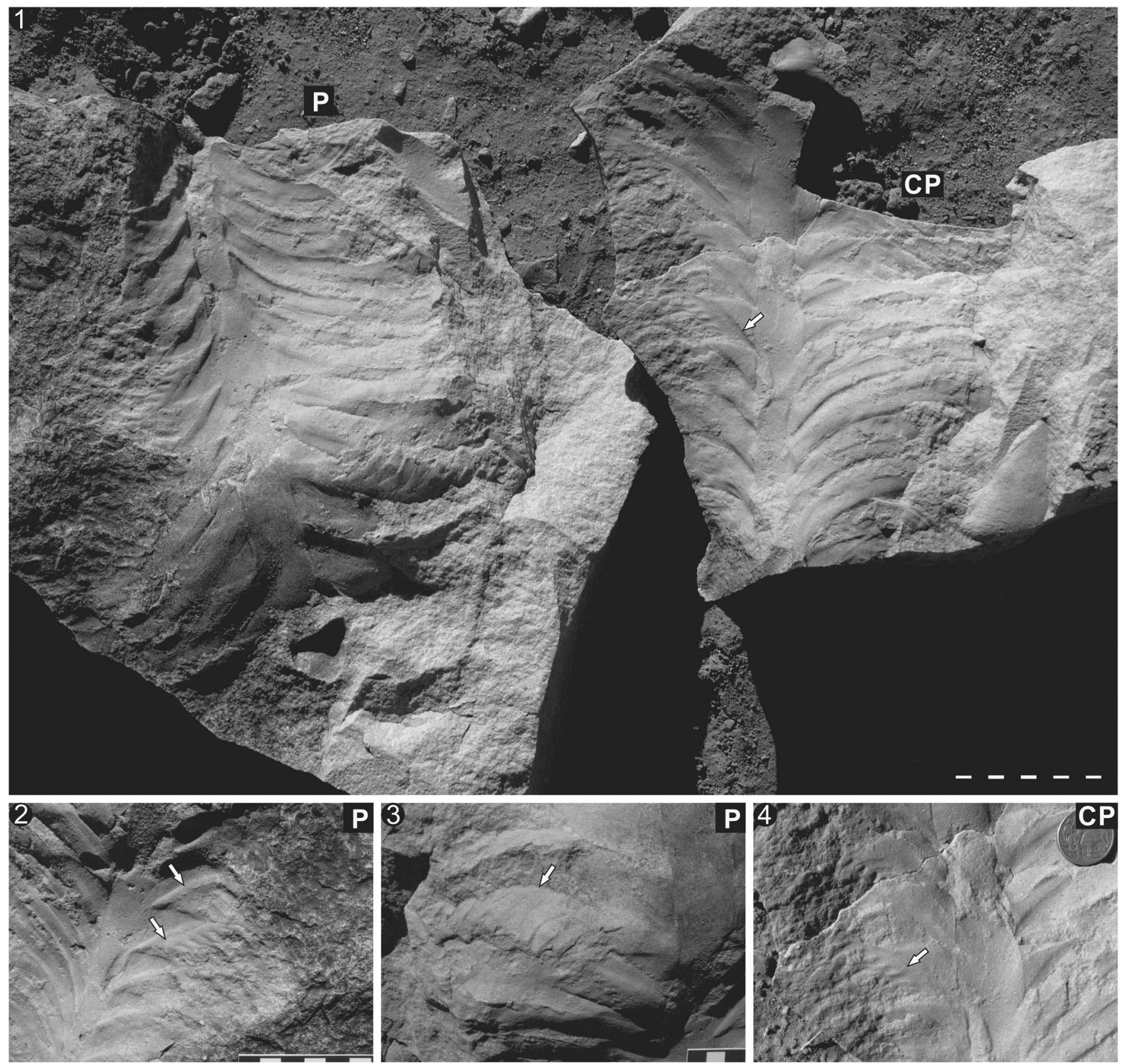

Figure 7. SAM P35704a, b from Nilpena Farm: (1) Part (P; facing downward) and counterpart (CP; facing upward) of SAM P35704a, b. (2-4) Secondary branches stemming from primary branching stalk and oriented in the opposite direction (directed proximally toward the base of the petaloid; arrows) from typical orientation. This suggests that the secondary branches are free and, under specific taphonomic settings, can come to rest in the opposite direction. Diameter of Australian $\$ 1$ coin $=2.5 \mathrm{~cm}$. Stalk, stem, and disc not preserved. Scale bars $=1 \mathrm{~cm}$ or $1 \mathrm{~cm}$ increments.

specimens displaying secondary elements (Jenkins and Gehling, 1978; Laflamme et al., 2004). Detailed study of numerous threedimensional specimens preserving the secondary branches may offer an additional explanation. As demonstrated in Figure 6, the primary branches are sausage-shaped and lack secondary branching. However, when the most distal branch is broken away (Fig. 6.2), a series of secondary branches presumably lying under the overlying primary branch are exposed. Secondary branches can be seen in their entirety as downwardly directed and teardrop-shaped structures (Fig. 6.2-6.4). As secondary branches are basally anchored to the primary branch stalk, which forms a midline in the center of the primary branch, the distal ends of secondary branches come to rest overtopping subsequent primary branches (Fig. 5.1-5.2), similar to overlapping shingles on a house. It is proposed that primary branches lacking secondary branches represent the dorsal side of the petalodium, and that secondary branch preservation is dependent on which side of the frond is cast. A second specimen preserved as both part and counterpart showcases the featureless, presumed dorsal side of the petalodium in addition to the secondary branches. In Figure 7, the proximal portions of the primary branches lack any morphological detail until a break in the distal portion of the rock (arrow in Fig. 7.1 CP) reveals the ventral side of the primary branch, complete with well-defined 

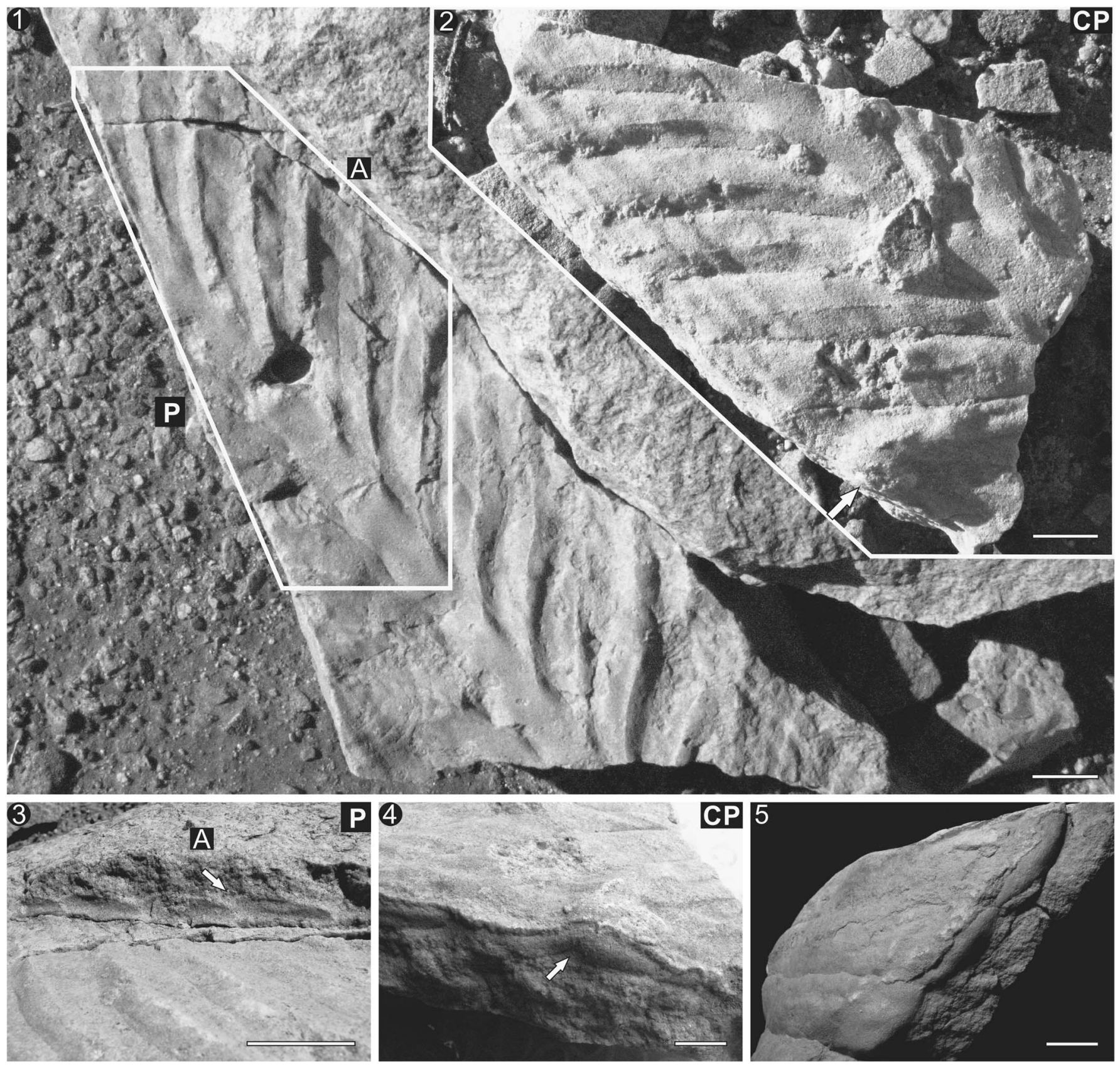

Figure 8. SAM P35703a, b from Nilpena Farm. (1) Part (P) and (2) counterpart (CP) of SAM P35703a, b with peapod-shaped primary branches and distinct central ridges representing primary branching stalks. (3) Side profile of primary branches indicating minimal frond thickness. White arrow indicates branch imbrications/overlap. (4) Branch overlapping resulting from displacement of a primary branch (white arrow). (5) Side profile demonstrating lobate distal terminations of primary branches and absence of a rim. All scale bars $=1 \mathrm{~cm}$.

secondary branches (Fig. 7.4). This apparent dorsal-ventral differentiation of the petalodium represents the simplest explanation for the preservation displayed in the three-dimensional specimens.

Restricting the secondary branches to a single side of the petalodium would have had significant consequences on the functional morphology of Arborea. It has been previously demonstrated that Ediacaran fronds in which the primary branches are all attached to one another (or to a sheet) could not have functioned in the same way as modern pennatulacean sea pens, which require a constant water flow between the primary branches to feed (Seilacher, 1992; Williams, 1997). Lacking the free-flow system between the primary branches, water currents would have reclined the fronds to varying degrees (Singer et al., 2012), with the stems allowing for structural rigidity and preventing the petaloids from being toppled. Densely packed frond meadows would also have led to a canopy-flow regime and favored upward growth and greater sizes (Ghisalberti et al., 2014). Furthermore, as the secondary branches were not attached to one another, currents were able to flow between them (rather than between the primary branches). This feeding mechanism is similar in many respects to modern pennatulacean feeding that requires water flow between the primary polyp leaves; however, in the absence of any visible tentacles or other 
food-capturing structures, it is difficult to interpret how food capture was achieved in Arborea. Tiering is presumed to have mostly been achieved through differences in the length of the stem, which would have been significantly sturdier than the petalodium, and may have been a driving force in Ediacaran speciation and evolution (Laflamme et al., 2004; Laflamme et al., 2012).

\section{Conclusions}

Newly discovered three-dimensional specimens of Arborea arborea from Nilpena Farm in the Flinders Ranges in South Australia allow for the reinterpretation of the morphology and function of this Ediacaran frond. The bifoliate petalodium and distinct branching morphology allow for Australian specimens of Charniodiscus arboreus to be reassigned to Arborea arborea.

Combined with well-preserved two-dimensional specimens, it is possible to isolate the morphological variation associated with the taphonomic process responsible for the preservation of soft-bodied Ediacara fossils and allow for a reconstruction of Arborea that can account for the variation in morphology between various taphomorphs. Arborea-type branching architecture highlights teardrop-shaped secondary branches on one side of the petalodium that were most likely the primary loci for nutrient absorption. Secondary branches were not attached to one another, which allowed for water to flow between these branches. Since the primary branches were likely stitched together or attached to a sheet, an epifaunal, recumbent life habit is implied for these fronds, allowing water currents to travel along the entire length of the petalodium where secondary branches could have absorbed dissolved organic nutrients directly from the water column.

\section{Acknowledgments}

Support to Laflamme was provided by the Natural Sciences and Engineering Research Council of Canada Discovery Grant (RGPIN 435402). Several key specimens were discovered by SA Museum volunteers M. Fuller, D. Rice, C. Armstrong, J. Perry, and S. Lange. Field work was supported by an Australian Research Council Discovery Grant (DP0453393) to Gehling. Excellent reviews were provided by A. Liu and an anonymous reviewer.

\section{References}

Bambach, R.K., Bush, A.M., and Erwin, D.H., 2007, Autecology and the filling of ecospace: Key metazoan radiations: Palaeontology, v. 50, p. 1-22.

Boag, T.H., Darroch, S.A.F., and Laflamme, M., 2016, Ediacaran distributions in space and time: Testing assemblage concepts of earliest macroscopic body fossils: Paleobiology, v. 42, p. 574-594.

Brasier, M.D., and Antcliffe, J.B., 2009, Evolutionary relationships within the Avalonian Ediacara biota: New insights from laser analysis: Journal of the Geological Society, London, v. 166, p. 363-384.

Brasier, M.D., Antcliffe, J.B., and Liu, A.G., 2012, The architecture of Ediacaran Fronds: Palaeontology, v. 55, p. 1105-1124.

Brasier, M.D., Liu, A.G., Menon, L.R., Matthews, J.J., Mcllroy, D., and Wacey, D., 2013, Explaining the exceptional preservation of Ediacaran rangeomorphs from Spaniard's Bay, Newfoundland: A hydraulic model: Precambrian Research, v. 231, p. 122-135.

Budd, G.E., and Jensen, S., 2015, The origin of the animals and a 'Savannah' hypothesis for early bilaterian evolution: Biological Reviews, v. 92, p. 446-473.
Burzynski, G., and Narbonne, G.M., 2015, The discs of Avalon: Relating discoid fossils to frondose organisms in the Ediacaran of Newfoundland, Canada: Palaeogeography, Palaeoclimatology, Palaeoecology, v. 434, p. 34-45.

Bush, A.M., Bambach, R.K., and Erwin, D.H., 2011, Ecospace utilization during the Ediacaran radiation and the Cambrian eco-explosion, in Laflamme, M. Schiffbauer, J.D., and Dornbos, S.Q., eds., Quantifying the Evolution of Early Life: Numerical and Technological Approaches to the Evaluation of Fossils and Ancient Ecosystems: Topics in Geobiology, v. 36: Dordrecht, The Netherlands, Springer, p. 111-133.

Callow, R.H.T., and Brasier, M.D., 2009, Remarkable preservation of microbial mats in Neoproterozoic siliciclastic settings: Implications for Ediacaran taphonomic models: Earth-Science Reviews, v. 96, p. 207-219.

Clapham, M.E., and Narbonne, G.M., 2002, Ediacaran epifaunal tiering: Geology, v. 30, p. 627-630.

Darroch, S.A.F., Laflamme, M., Schiffbauer, J.D., and Briggs, D.E.G., 2012 Experimental formation of a microbial death mask: Palaios, v. 27, p. 293-303.

Darroch, S.A.F., Sperling, E.A., Boag, T.H., Racicot, R.A., Mason, S.J. Morgan, A.S., Tweedt, S., Myrow, P., Johnston, D.T., Erwin, D.H., and Laflamme, M., 2015, Biotic replacement and mass extinction of the Ediacara biota: Proceedings of the Royal Society B-Biological Sciences, v. 282 , p. $129-138$

Darroch, S.A.F., Boag, T.H., Racicot, R.A., Tweedt, S., Mason, S.J., Erwin, D.H., and Laflamme, M., 2016, A mixed Ediacaran-metazoan assemblage from the Zaris Sub-basin, Namibia: Palaeogeography, Palaeoclimatology, Palaeoecology, v. 459, p. 198-208.

Dececchi, T.A., Narbonne, G.M., Greentree, C., and Laflamme, M., 2017, Relating Ediacaran fronds: Paleobiology, v. 43, p. 171-180.

Droser, M.L., and Gehling, J.G., 2015, The advent of animals: The view from the Ediacaran: Proceedings of the National Academy of Sciences USA, v. 112, p. 4865-4870.

Droser, M.L., Gehling, J.G., and Jensen, S.R., 2006, Assemblage palaeoecology of the Ediacara biota: The unabridged edition?: Palaeogeography, Palaeoclimatology, Palaeoecology, v. 232, p. 131-147.

Dzik, J., 1999, Organic membranous skeleton of the Precambrian metazoans from Namibia: Geology, v. 27, p. 519-522.

Dzik, J., 2002, Possible ctenophoran affinities of the Precambrian "seapen" Rangea: Journal of Morphology, v. 252, p. 315-334.

Erwin, D.H., Laflamme, M., Tweedt, S.M., Sperling, E.A., Pisani, D., and Peterson, K.J., 2011, The Cambrian conundrum: Early divergence and later ecological success in the early history of animals: Science, v. 334,p. 1091-1097.

Fedonkin, M.A., and Waggoner, B.M., 1997, The late Precambrian fossil Kimberella is a mollusc-like bilaterian organism: Nature, v. 388, p. 868-871.

Ford, T.D., 1958, Precambrian fossils from Charnwood Forest: Proceedings of the Yorkshire Geological Society, v. 31, Pt. 3, p. 211-217.

Gehling, J.G., 1999, Microbial mats in terminal Proterozoic siliciclastics: Ediacaran death masks: Palaios, v. 14, p. 40-57.

Gehling, J.G., 2000, Environmental interpretation and a sequence stratigraphic framework for the terminal Proterozoic Ediacara Member within the Rawnsley Quartzite, South Australia: Precambrian Research, v. 100, p. 65-95.

Gehling, J.G., and Droser, M.L., 2009, Textured organic surfaces associated with the Ediacara biota in South Australia: Earth-Science Reviews, v. 96 , p. 196-206.

Gehling, J.G., and Droser, M.L., 2013, How well do fossil assemblages of the Ediacara biota tell time? Geology, v. 41, p. 447-450

Gehling, J.G., Droser, M.L., Jensen, S., and Runnegar, B.N., 2005, Ediacaran organisms: Relating form to function, in Briggs, D.E.G., ed., Evolving Form and Function: Fossils and Development, Proceedings of a Symposium Honoring Adolf Seilacher for His Contributions to Palaeontology in Celebration of His 80th Birthday: New Haven, Connecticut, Peabody Museum of Natural History, Yale University, p. 43-67.

Germs, G.J.B. 1973, A reinterpretation of Rangea schneiderhoehni and the discovery of a related new fossil from the Nama Group, South West Africa. 6, 1-10.

Ghisalberti, M., Gold, D., Laflamme, M., Clapham, M.E., Narbonne, G.M., Summons, R.E., Johnston, D.T. and Jacobs., D.K., 2014, Canopy flow analysis reveals the advantage of size in the oldest communities of multicellular eukaryotes: Current Biology, v. 24, p. 305-309.

Glaessner, M.F., 1979, Biogeography and biostratigraphy: Precambrian, in Moore, R.C. (founder), Robinson, R.A., and Teichert, C., eds., Treatise on Invertebrate Paleontology, Pt. A, Introduction, Fossilization (Taphonomy), Biogeography and Biostratigraphy: Boulder, Colorado, Geological Society of America: Lawrence, Kansas, University of Kansas Press, p. 79-118.

Glaessner, M.F., and Daily, B., 1959, The geology and late Precambrian fauna of the Ediacara fossil reserve: Records of the South Australian Museum, v. 13, p. 369-407.

Glaessner, M.F., and Wade, M., 1966, The late Precambrian fossils from Ediacara, South Australia: Palaeontology, v. 9, p. 599-628.

Grazhdankin, D.V., 2014, Patterns of evolution of the Ediacaran soft-bodied biota: Paleontology, v. 45 , p. $57-78$ 
Grazhdankin, D.V., Balthasar, U., Nagovitsin, K.E., and Kochnev, B.B., 2008, Carbonate-hosted Avalon-type fossils in arctic Siberia: Geology, v. 36, p. 803-806.

Gurich, G. 1929, Die altesten fossilien Sudafrika. Zeitschrift fur Praktische Geologie, 37:85.

Gurich, G. 1930, Die bislang altesten Spuren von Organismen in Sudafrika. In: XV International Geological Congress, South Africa, 1929, 2, 670-680.

Ivantsov, A.Y., 2016, Reconstruction of Charniodiscus yorgensis (macrobiota from the Vendian of the White Sea): Paleontological Journal, v. 50, p. $1-12$.

Ivantsov, A.Y., Narbonne, G.M., Trusler, P.W., Greentree, C., and VickersRich, P., 2016, Elucidating Ernietta: New insights from exceptional specimens in the Ediacaran of Namibia: Lethaia, v. 49, p. 540-554.

Jenkins, R.J.F., 1996, Aspects of the geological setting and palaeobiology of the Ediacara assemblage, in Davies, M., Twidale, C.R., and Tyler, M.J., eds., Natural History of the Flinders Ranges, v. Vol. 7: Richmond, South Australia, Royal Society of South Australia, p. 33-45.

Jenkins, R.J.F., and Gehling, J.G., 1978, A review of the frond-like fossils of the Ediacara assemblage: Records of the South Australian Museum, v. 17, p. 347-359.

Jenkins, R.J.F. 1985, The enigmatic Ediacaran (late Precambrian) genus Rangea and related forms. Paleobiology, 11:336-355.

Kenchington, C.G., and Wilby, P., 2014, Of time and taphonomy: Preservation in the Ediacaran, in Laflamme, M., Schiffbauer, J.D., and Darroch, S.A.F., eds., Reading and Writing of the Fossil Record: Preservational Pathways to Exceptional Fossilization: Geological Society of America Paleontological Society Papers series, v. 20, p. 101-122.

Knoll, A.H., Walter, M.R., Narbonne, G.M., and Christie-Blick, N., 2006, The Ediacaran Period: A new addition to the geologic time scale: Lethaia, v. 39, p. $13-30$.

Laflamme, M., and Narbonne, G.M., 2008a, Competition in a Precambrian world: Palaeoecology of Ediacaran fronds: Geology Today, v. 24, p. 182-187.

Laflamme, M., and Narbonne, G.M., 2008b, Ediacaran fronds: Palaeogeography, Palaeoclimatology, Palaeoecology, v. 258, p. 162-179.

Laflamme, M., Narbonne, G.M., and Anderson, M.M., 2004, Morphometric analysis of the Ediacaran frond Charniodiscus from the Mistaken Point Formation, Newfoundland: Journal of Paleontology, v. 78, p. 827-837.

Laflamme, M., Narbonne, G.M., Greentree, C., and Anderson, M.M., 2007, Morphology and taphonomy of an Ediacaran frond: Charnia from the Avalon Peninsula of Newfoundland, In Vickers-Rich, P., and Komarower, P., eds., The Rise and Fall of the Ediacaran Biota: Geological Society Special London, v. 286, p. 237-257.

Laflamme, M., Schiffbauer, J.D., Narbonne, G.M., and Briggs, D.E.G., 2011, Microbial biofilms and the preservation of the Ediacara biota: Lethaia, v. 44, p. 203-213.

Laflamme, M., Flüde, L.I., and Narbonne, G.M, 2012, Ecological tiering and the evolution of a stem: The oldest stemmed frond from the Ediacaran of Newfoundland, Canada: Journal of Paleontology, v. 86, p. 193-200.

Laflamme, M., Darroch, S.A.F., Tweedt, S., Peterson, K.J., and Erwin, D.H., 2013, The end of the Ediacara biota: Extinction, biotic replacement, or Cheshire cat?: Gondwana Research, v. 23, p. 558-573.

Liu, A.G., 2016, Framboidal pyrite shroud confirms the 'death mask' model for moldic preservation of Ediacaran soft-bodied organisms: Palaios, v. 31, p. 259-274.

Liu, A.G., Mcllroy, D., and Brasier, M.D., 2010, First evidence for locomotion in the Ediacara biota from the 565 Ma Mistaken Point Formation, Newfoundland: Geology, v. 38, p. 123-126.

Liu, A.G., McIlroy, D., Antcliffe, J.B., and Brasier, M.D., 2011, Effaced preservation in the Ediacara biota and its implications for the early macrofossil record: Palaeontology, v. 54, p. 607-630.

MacGabhann, B.A., 2014, There is no such thing as the 'Ediacara Biota': Geoscience Frontiers, v. 5, p. 53-62.
Martin, M.W., Grazhdankin, D.V., Bowring, S.A., Evans, D.A.D., Fedonkin, M.A., and Kirschvink, J.L., 2000, Age of Neoproterozoic bilatarian body and trace fossils, White Sea, Russia: Implications for metazoan evolution: Science, v. 288, p. 841-845.

Matthews, J.J., Liu, A.G., and McIlroy, D., 2017, Post-fossilization processes and their implications for understanding Ediacaran macrofossil assemblages: Geological Society, London, Special Publications, v. 448, p. 251-269.

Menon, L.R., McIlroy, D., and Brasier, M.D., 2013, Evidence for Cnidaria-like behavior in ca. 560 Ma Ediacaran Aspidella: Geology, v. 41, p. 895-898.

Narbonne, G.M., 2004, Modular construction of early Ediacaran complex life forms: Science, v. 305, p. 1141-1144.

Narbonne, G.M., 2005, The Ediacaran biota: Neoproterozoic origin of animals and their ecosystems: Annual Review of Earth Planet Sciences, v. 33 , p. $421-442$.

Narbonne, G.M., Saylor, B.Z., and Grotzinger, J.P., 1997, The youngest Ediacaran fossils from Southern Africa: Journal of Paleontology, v. 71, p. 953-967.

Narbonne, G.M., Dalrymple, R.W., and Gehling, J.G., 2001, Neoproterozoic fossils and environments of the Avalon Peninsula, Newfoundland. Field Trip B5: Geological Association of Canada-Mineralogical Association of Canada Joint Annual Meeting, St. John's, Newfoundland, 98 p.

Narbonne, G.M., Laflamme, M., Greentree, C., and Trusler, P., 2009, Reconstructing a lost world: Ediacaran Rangeomorphs from Spaniard's Bay, Newfoundland: Journal of Paleontology, v. 83, p. 503-523.

Seilacher, A., 1992, Vendobionta and Psammocorallia: Lost constructions of Precambrian evolution: Journal of the Geological Society of London, v. 149 , p. $607-613$.

Schiffbauer, J.D., Xiao, S., Cai, Y., Wallace, A.F., Hua, H., Hunter, J., Xu, H., Peng, Y., and Kaufman, A.J., 2014, A unifying model for NeoproterozoicPalaeozoic exceptional fossil preservation through pyritization and carbonaceous compression: Nature Communications, v. 5, p. 5754.

Schiffbauer, J.D., Huntley, J.W., O'Neil, G.R., Darroch, S.A.F., Laflamme, M., and Cai, Y., 2016, The latest Ediacaran wormworld fauna: Setting the ecological stage for the Cambrian explosion: GSA Today, v. 26, p. 4-11.

Singer, A., Plotnick, R.E., and Laflamme, M., 2012, Experimental fluid mechanics of an Ediacaran Frond: Palaeontologia Electronica, v. 15, $14 \mathrm{p}$.

Tarhan, L.G., Gehling, J.G., and Droser, M.L., 2010, Taphonomic controls on Ediacaran diversity: Uncovering the holdfast origin of morphologically variable enigmatic structures: Palaios, v. 25, p. 823-830.

Tarhan, L.G., Hood, A.S., Droser, M.L., Gehling, J.G., and Briggs, D.E.G., 2016, Exceptional preservation of soft-bodied Ediacara Biota promoted by silica-rich oceans: Geology, v. 44, p. 951-954.

Vickers-Rich, P., et al., 2013, Reconstructing Rangea: New Discoveries from the Ediacaran of Southern Namibia: Journal of Paleontology, v. 87, p. 1-15.

Waggoner, B., 2003, The Ediacaran biotas in space and time: Integrated and Comparative Biology, v. 43, p. 104-113.

Williams, G.C., 1997, Preliminary assessment of the phylogeny of Pennatulacea (Anthozoa: Octocorallia), with a re-evaluation of Ediacaran frond-like fossils, and synopsis of the history of evolutionary thought regarding the sea pens, in den Hartog, J.C., ed., Coelenterate Biology: Proceedings of the 6th International Conference of Coelenterate Biology, Leiden, Nationaal Natuurhistorisch Museum, p. 497-509.

Xiao, S., and Laflamme, M., 2009, On the eve of animal radiation: Phylogeny, ecology, and evolution of the Ediacara Biota: Trends in Ecology and Evolution, v. 24, p. 31-40.

Xiao, S., Droser, M., Gehling, J.G., Hughes, I.V., Wan, B., Chen, Z., and Yuan, X., 2013, Affirming life aquatic for the Ediacara biota in China and Australia: Geology, v. 41, p. 1095-1098.

Accepted 27 September 2017 